\title{
APLIKASI DESKTOP SISTEM TRIASE UNTUK PENDUKUNG PRIORITAS TINGKAT KEGAWATAN
}

\author{
Yosep Agus Pranoto ${ }^{1}$, Suryo Adi Wibowo ${ }^{2}$ \\ ${ }^{1,2}$ Teknik Informatika S1 Institut Teknologi Nasional Malang \\ yoa@lecturer.itn.ac.id
}

\begin{abstract}
ABSTRAK
Pelayanan di Unit Gawat Darurat (UGD) didasarkan pada tingkat kegawatan pasien. Pasien yang datang lebih awal belum tentu segera dilakukan tindakan medis. Kondisi seperti ini yang menyebabkan pelayanan seolah - olah terasa lambat. Triase adalah usaha pemilahan korban sebelum ditangani, berdasarkan tingkat kegawat - daruratan trauma atau penyakit dengan mempertimbangkan prioritas penanganan dan sumber daya yang ada. Salah satu metode yang di gunakan pada Triase adalah metode Simple Triage and Rapid Treatment (START). Pelaksanaan metode ini adalah memilah pasien dengan memberi tanda warna berdasarkan prosedur - prosedur yang sudah ditetapkan. Dalam keadaan yang darurat, faktor psikis dapat menyebabkan potensi terjadinya kesalahan dalam memilah pasien berdasarkan tingkat kegawatannya, teruma pada rumah sakit besar dengan jumlah pasien di UGD yang banyak.

Seiring dengan berkembangnya teknologi informasi, proses triase menggunakan metode START dapat dikembangkan secara terkomputerisasi dengan membuat aplikasi berbasis komputer. Tujuannya adalah dapat mempercepat dan mengurangi tingkat kesalahan pada saat melakukan proses triase karena faktor human error sering kali terjadi pada saat kondisi darurat. Fitur pada aplikasi ini selain menu untuk klasifikasi pasien, juga terdapat menu biodata dan label warna pasien sebagai tanda tingkat kegawatan. Pada penelitian ini dibuat aplikasi triase menggunakan metode START berbasis komputer.

Hasil pengujian fungsional menunjukkan bahwa semua fitur aplikasi triase $100 \%$ dapat berjalan sesuai dengan yang diharapkan. Hasil proses klasifikasi kegawatan pasien pada aplikasi Triase menggunakan metode START ini sudah sesuai dengan rule yang telah ditetapkan.
\end{abstract}

Keyword : Triase, metode START

\section{PENDAHULUAN}

UGD (Unit Gawat Darurat) merupakan bagian vital dari rumah sakit atau klinik karena saat pasien datang akan langsung dilakukan tindakan medis di tempat ini sebagai langkah awal pertolongan. Pasien yang datang sangat beragam jenis penyakitnya, baik penyakit berat, sedang maupun ringan. Setiap pasien menginginkan proses pelayanan yang cepat dari pihak UGD, namun sering kali kurang sesuai dengan harapan. Pasien yang datang lebih awal belum tentu akan mendapatkan tindakan medis lebih dahulu, begitu pula sebaliknya adakalanya pasien yang baru datang tetapi mendapat tindakan medis terlebih dahulu.

Berdasarkan fenomena tersebut, ternyata sebelum melakukan tindakan medis, pihak UGD terlebih dahulu melakukan pemilahan pasien berdasarkan tingkat kegawatannya atau dikenal dengan prinsip Triase. Prinsip ini diterapkan terutama di rumah sakit besar yang notabene memiliki banyak antrian pasien di UGD. Salah satu metode yang digunakan pada prinsip Triase adalah Simple Triage and Rapid Treatment (START). Pada metode ini melakukan pemilahan tingkat kegawatan pasien dengan memberikan tanda merah, kuning, hijau dan hitam (Hogan dan Burstein, 2007). Proses pemilahan menggunakan prosedur - prosedur yang sudah ditetapkan pada metode START. Dalam kondisi darurat, seringkali berpotensi terjadinya kesalahan dalam memilah pasien. Kondisi psikis, tubuh yang lelah dan keadaan yang genting merupakan salah satu faktor yang menyebabkan terjadinya kesalahan dalam menentukan kegawatan pasien. Dampaknya adalah menurunnya kualitas pelayanan dan harapan hidup pasien.

Dengan berkembang pesatnya teknologi informasi dan komunikasi diharapkan dapat menjangkau menyelesaikan permasalahan yang terjadi di bidang kesehatan. Pada penelitian ini dibuat aplikasi Triase menggunakan metode START untuk membantu mempermudah dan mempercepat klasifikasi kegawatan pasien. Dengan menggunakan aplikasi ini, diharapkan penanganan pasien bisa lebih efektif sehingga kualitas hidup pasien bisa menjadi lebih baik.

\section{LANDASAN TEORI}

\subsection{Simple Triage and Rapid Treatment} (START)

START, merupakan metode Triase yang paling sederhana dan cepat. Adapun langkah langkah metode START yaitu (Hogan dan Burstein, 2007):

a. Pasien yang datang tetapi masih bisa berjalan sendiri, maka diberi label HIJAU.

b. Periksa pernapasan pasien :

1) Apabila frekwensi pernapasan lebih dari $30 \mathrm{kali}$ dalam satu menit, maka pasien diberikan label MERAH. 
2) Apabila pasien tidak bernapas, maka berikan pertolongan dengan cara membuka jalan pernapasan dan membersihkan jalan napas sebanyak satu kali. Apabila secara spontan pasien bisa bernapas, maka berikan label MERAH. Namun apabila tidak, maka berikan label HITAM.

3) Apabila pernapasan kurang dari 30 kali dalam satu menit, maka periksalah waktu pengisian kapiler.

c. Waktu pengisian kapiler pasien :

1) Apabila waktu pengisian kapiler lebih dari 2 detik, maka pasien diberi label MERAH, hentikan perdarahan besar apabila ada.

2) Apabila waktu pengisian kapiler kurang dari 2 detik, maka lakukan penilaian status mental pasien.

3) Apabila penerangan kurang, maka periksa nadi radial penderita. Apabila tidak ada, maka artinya adalah tekanan darah pasien sudah rendah dan perfusi jaringan sudah menurun.

e. Pemeriksaan status mental pasien:

1) Pasien diperiksa dengan cara memberikan instruksi untuk mengikuti perintah-perintah sederhana

2) Pasien diberi label MERAH apabila tidak mampu mengikuti perintah - perintah yang sederhana

3) Pasien diberi label KUNING apabila mampu mengikuti perintah - perintah yang sederhana.

\subsection{Flowchart}

Flowchart menggambarkan urutan logika dari suatu prosedur pemecahan masalah, sehingga flowchart merupakan langkah - langkah penyelesaian masalah yang dituliskan dengan simbol - simbol tertentu. Flowchart merupakan gambar dari sebuah algoritma untuk menyelesaikan sebuah permasalahan. Dalam menggambarkan sebuah flowchart terdapat aturan - aturan yang harus dipahami dan diikuti, hal ini karena flowchart juga sebagai alat untuk komunikasi dan dokumentasi programmer dalam membuat program. Aturan aturan dalam perancangan flowchart, yaitu :

1. Arah penulisan flowchart dari atas ke bawah atau dari kiri ke kanan.

2. Setiap proses dalam flowchart harus dinyatakan secara jelas dan tegas (eksplisit).

3. Flowchart harus dimulai dari kondisi start dan berakhir di satu atau lebih kondisi end.

4. Connector atau off page connector state dengan label yang sama digunakan apabila flowchart terpotong karena ganti halaman tetapi masih ada hubungan algoritma. (Sitorus,2015).

Tujuan dari flowchart adalah digunakan untuk menggambarkan suatu tahapan penyelesaian masalah secara sederhana, terurai, rapi dan jelas menggunakan simbol - simbol yang standart.

\subsection{Database}

Database atau basis data adalah sekumpulan data yang saling berhubungan. Definisi data yaitu merupakan fakta mengenai obyek, orang dan lain lain yang dinyatakan dengan nilai (angka, deretan karakter atau simbol).

Manfaat atau kelebihan basis data yaitu (Kusrini, 2007):

1. Lebih cepat dan mudah (speed)

2. Data dapat dipakai secara bersama - sama (sharebility)

3. Kontrol data yang terpusat

4. Ruang penyimpanan yang efisien (space)

5. Memiliki Keakuratan yang tinggi (accuracy)

6. Ketersediaan data yang handal (availability)

7. Data tersedia secara lengkap (completeness)

8. Faktor keamanan yang tinggi(Security)

9. Dengan menggunakan database, maka mudah untuk membuat program aplikasi baru.

10. Pemakaian secara langsung

11. Kebebasan data (data independence)

12. User view

\subsection{Microsoft Access}

Microsoft Access adalah sebuah software yang dibuat oleh Microsoft dengan tujuan khusus untuk menyimpan dan mengelola data secara database. Saat ini banyak sekali software yang digunakan untuk mengolah database seperti foxpro, sql server, mysql, oracle dan lain - lain. Namun, Saat ini software database yang mudah dan instan tidak ada lagi selain Microsoft Access. Di dalam Microsoft Access kita bisa membuat tabel untuk menyimpan data, membuat form, report dan program aplikasi untuk mengelola data.

Adapun keunggulan apabila kita menggunakan Microsoft Access antara lain (Talib,2014):

1.Proses pemasukan data yang mudah dan hampir sama dengan Microsoft Excel.

2.Datasheet view dapat digunakan untuk menampilkan isi tabel, entry, edit dan delete data tanpa perlu membuat apapun.

3.Duplikasi data data dikurangi karena aturan database dapat diimplementasikan pada Microsoft Access.

4.Adanya fasilitas form menjadikan proses pemasukan data lebih mudah.

5.Adanya fasilitas query, informasi dapat dihasilkan sesuai dengan kebutuhan user baik dalam bentu datasheet, form dan report.

6.Data bisa dipakai oleh beberapa orang secara bersama - sama (multi user).

7.Untuk mengurangi pekerjaan yang berulangulang, pada Microsoft Access bisa dibuat program aplikasi yang berjalan secara otomatis.

8.Adanya fitur keamanan (security) yang lebih baik. 


\subsection{Delphi}

Borland Delphi adalah sebuah (tool) alat yang digunakan untuk pengembangan aplikasi - aplikasi berbasis sistem operasi Windows. Delphi sangat berguna dan mudah digunakan untuk membuat program berbasis graphical user interface (GUI) atau console (mode teks).

Delphi merupakan bahasa pemrograman pertama yang memecahkan batasan antara bahasa tingkat tinggi dan pengembangan aplikasi dengan cepat (Rapid Application Development /RAD).

Kelebihan Borland Delphi antara lain :

1. Delphi merupakan bahasa pemrograman yang mendukung OOP (Obejct Oriented Programming)

2. Dengan menggunakan Dephi, aplikasi dapat dikembangkan secara cepat (Rapid Application Development/RAD).

3. Bahasa pemrograman Delphi menggunakan bahasa tingkat tinggi, sehingga mudah sekali untuk dimengerti. Hasil kompilasi dari Delphi berupa berupa sebuah file exe yang dapat dieksekusi (Executable File). Dampaknya adalah proses distribusi program lebih mudah dan dapat mengurangi file DLL (file pendukung).

4. Ketersediaan komponen Delphi yang melipah. Banyak pihak ketiga yang mengembangkan komponen Delphi dengan disertai dokumentasi, kode sumber baik yang free maupun komersil.

5. Mudah dalam membuat aplikasi databse berbasis jaringan, karena Delphi mendukung banyak jenis database server seperti MySQL, SQL Server, Interbase, Oracle dan sebagainya. (Andoyo dan Suyono,2016).

\section{PERANCANGAN}

\subsection{Kebutuhan Sistem}

Dalam penelitian ini beberapa target yang digunakan untuk kebutuhan fungsional adalah:

1. Aplikasi ini dapat melakukan klasifikasi penanganan pasien berdasarkan tingkat kegawatan yang dialami pasien.

2. Metode triage yang digunakan yaitu Simple Triage and Rapid Treatment (START).

3. Perangkat lunak yang digunakan dalam pembuatan aplikasi ini adalah delphi 7.

\subsection{Struktur Menu Aplikasi}

Aplikasi Triage menggunakan metode START memiliki 4 halaman menu, yaitu menu utama, pendataan pasien, diagnosa pasien dan klasifikasi pasien. Struktur menu aplikasi triage ditunjukkan pada Gambar 1.

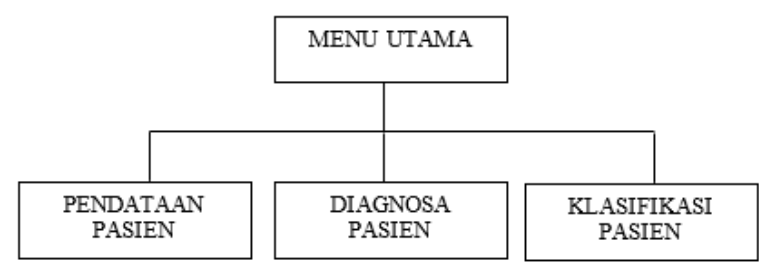

Gambar 1 Struktur Menu Aplikasi Triage Menggunakan metode START

\subsection{Rancangan Form Aplikasi}

Aplikasi Triase menggunakan metode START yang dibuat pada penelitian ini memiliki 4 form, yaitu form menu utama, form pendataan pasien, form diagnosa pasien dan form klasifikasi pasien. Rancangan form utama ditunjukkan pada Gambar 2.

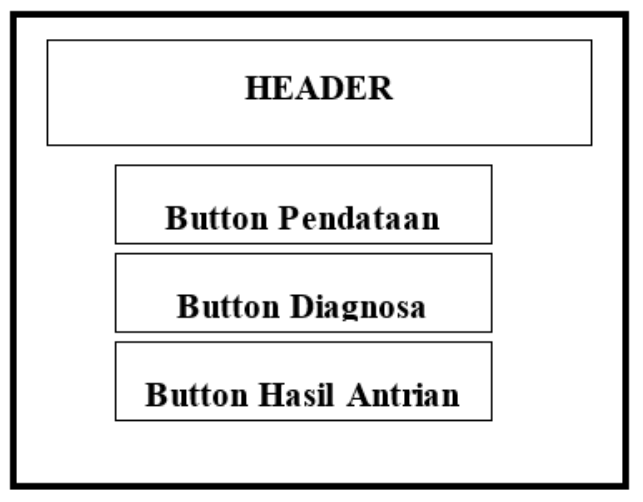

Gambar 2 Rancangan form utama aplikasi

Rancangan form pendataan pasien ditunjukkan pada Gambar 3

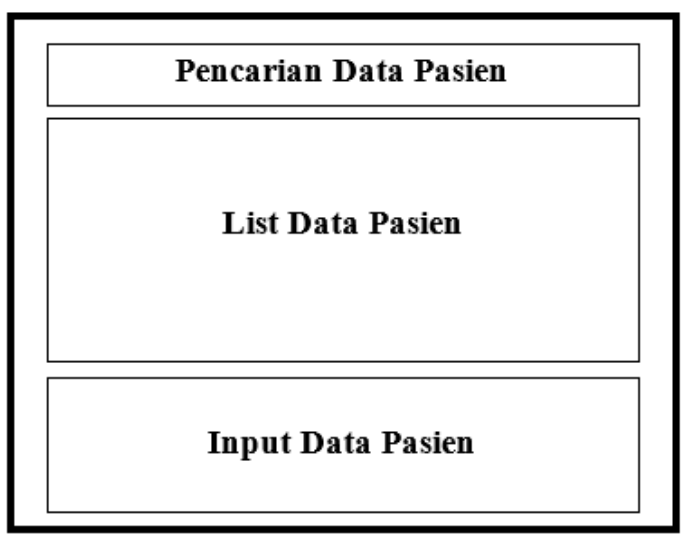

Gambar 3 Rancangan form Pendataan Pasien

Rancangan form diagnosa pasien ditunjukkan pada Gambar 4 


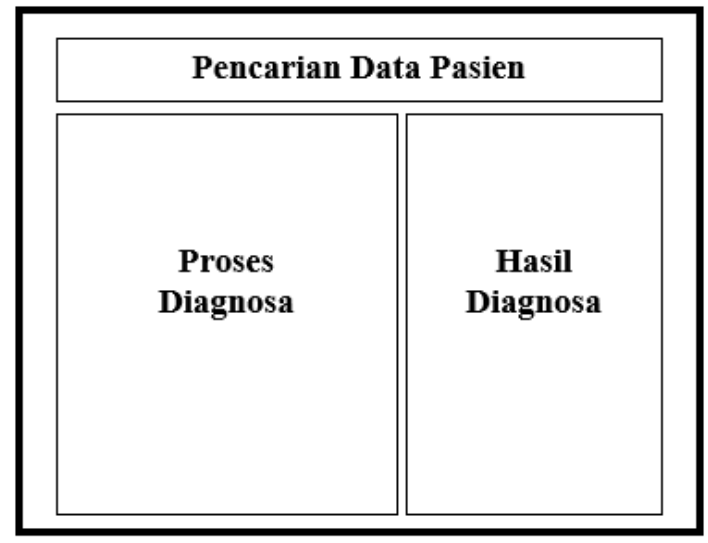

Gambar 4 Rancangan form Diagnosa Pasien

Rancangan form hasil klasifikasi pasien ditunjukkan pada Gambar 5

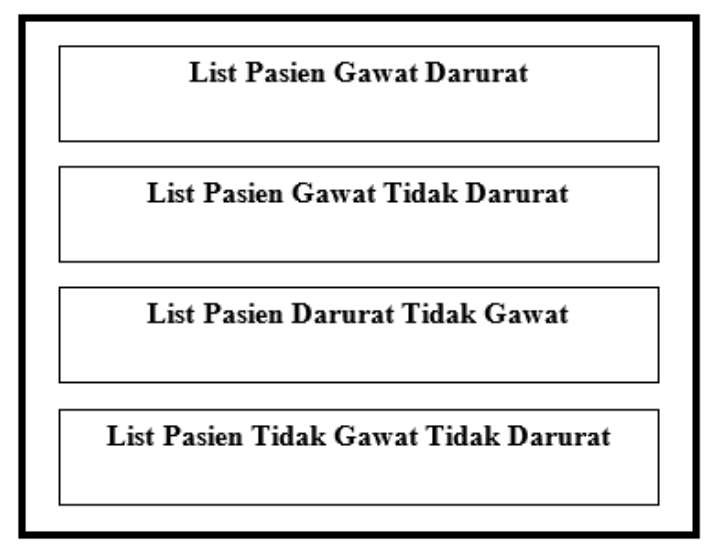

Gambar 5 Rancangan form hasil klasifikasi pasien

\subsection{Tabel Rule Triase Menggunakan Metode START pada Aplikasi}

Tabel rule triase menggunakan metode START pada aplikasi ditunjukkan pada Tabel 1

Tabel 1 Rule Triase metode START pada aplikasi

\begin{tabular}{|c|c|c|c|c|c|c|c|}
\hline Gejala & Label & Label & & abel & Iera & & Label \\
\hline Dapat berjalan & $\mathrm{v}$ & & & & & & \\
\hline Dapat bernafas & & $\mathrm{v}$ & & $\mathrm{v}$ & $\mathrm{v}$ & $\mathrm{v}$ & \\
\hline $\begin{array}{l}\text { Dapat bernafas setelah } \\
\text { jalan nafas dibuka }\end{array}$ & & & $\mathrm{v}$ & & & & \\
\hline $\begin{array}{l}\text { Frekwensi pernafasan }>= \\
30 \mathrm{x}\end{array}$ & & & & & $\mathrm{v}$ & & \\
\hline $\begin{array}{l}\text { Waktu pengisian kapiler } \\
>=2 \text { detik }\end{array}$ & & & & & & $\mathrm{v}$ & \\
\hline $\begin{array}{l}\text { Status mental perintah } \\
\text { sederhana }\end{array}$ & & $\mathrm{v}$ & & & & & \\
\hline
\end{tabular}

\subsection{Flowchart Triase MenggunakanMetode START}

Flowchart triase menggunakan metode START ditunjukkan pada Gambar 6.

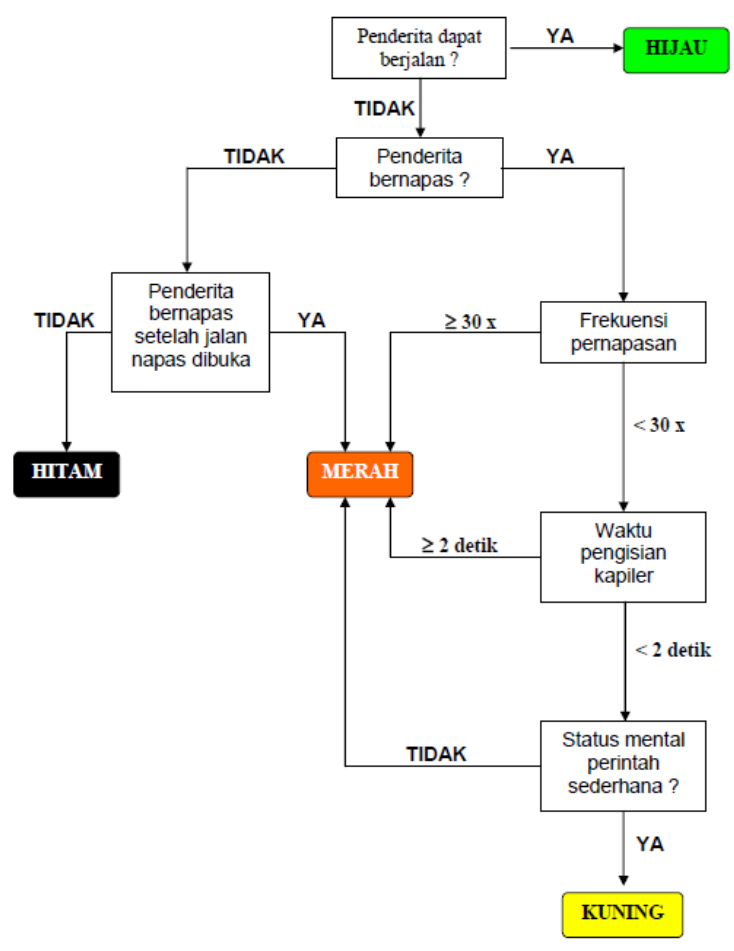

Gambar 6 Flowchart Triase menggunakan Metode START (Hogan dan Burstein, 2007)

\subsection{Rancangan Tabel Database}

Terdapat beberapa tabel yang digunakan pada aplikasi ini, antara lain tabel DATA_PASIEN, tabel LABEL_HIJAU, tabel LABEL_MERAH, tabel LABEL_KUNING dan tabel LABEL_HITAM. Rancangan tabel DATA_PASIEN ditunjukkan pada Tabel 2.

Tabel 2 Rancangan tabel DATA_PASIEN

\begin{tabular}{|l|c|c|}
\hline \multicolumn{1}{|c|}{ Nama Field } & Tipe Data & Length \\
\hline NO & Short Text & 10 \\
\hline NAMA & Short Text & 30 \\
\hline ALAMAT & Short Text & 50 \\
\hline AGAMA & Short Text & 20 \\
\hline JENIS_KELAMIN & Short Text & 25 \\
\hline TEMPAT_LAHIR & Short Text & 50 \\
\hline TANGGAL_LAHIR & Short Text & 10 \\
\hline
\end{tabular}

Tabel LABEL_HIJAU, tabel LABEL_MERAH, tabel LABEL_KUNING dan tabel LABEL_HITAM memiliki rancangan yang sama dan ditunjukkan pada Tabel 3. 
Tabel 3 Rancangan tabel LABEL_HIJAU, tabel LABEL_MERAH, tabel TABEL_KUNING Dan tabel LABEL HITAM

\begin{tabular}{|l|c|c|}
\hline \multicolumn{1}{|c|}{ Nama Field } & Tipe Data & Length \\
\hline NO & Short Text & 10 \\
\hline NAMA & Short Text & 30 \\
\hline ALAMAT & Short Text & 50 \\
\hline JENIS_KELAMIN & Short Text & 25 \\
\hline
\end{tabular}

\section{PEMBAHASAN DAN PENGUJIAN}

\subsection{Pembahasan}

Form utama aplikasi triase menggunakan metode START ditunjukkan pada Gambar 7

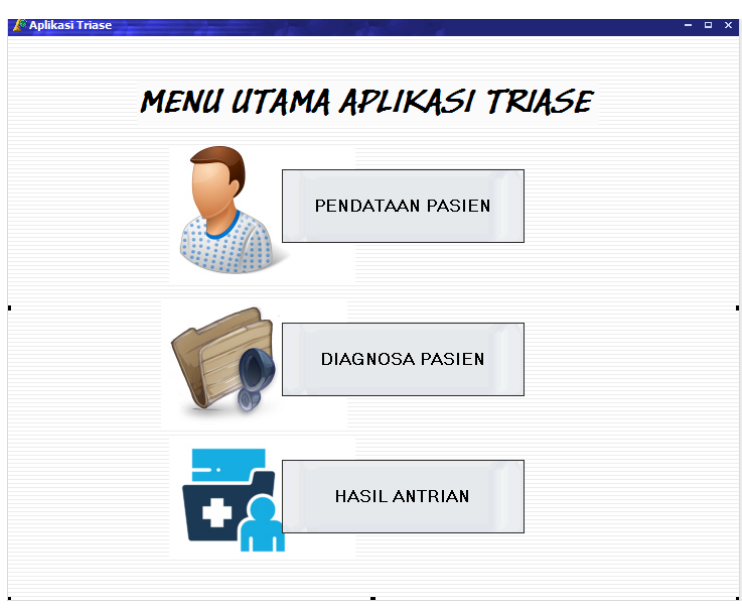

Gambar 7 Form Utama Aplikasi Triase

Pada form utama terdapat 3 tombol yang digunakan membuka form pendataan pasien, form diagnose pasien dan form hasil antrian. Form pendataan pasien digunakan untuk melakukan input biodata yang meliputi data ID pasien, nama, alamat, agama, jenis kelamin, tempat lahir dan tanggal lahir. Form input data pasien ditunjukkan pada Gambar 8

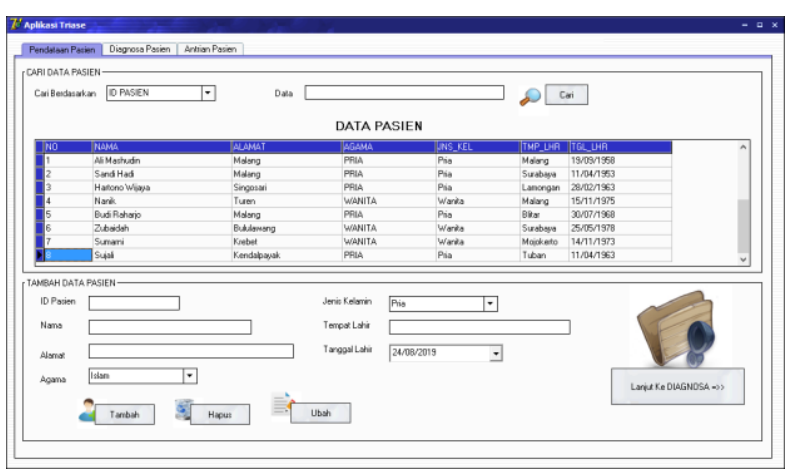

Gambar 8 Form Input Data Pasien
Form diagnose pasien digunakan untuk proses triase menggunakan metode START. Pada form ini berisikan ID pasien, nama pasien sesuai input pada form pendataan pasien serta gejala - gejala yang dialami oleh pasien. Program secara otomatis menganalisa sesuai dengan rule yang diberikan. Gambar 9 menunjukkan hasil triase dengan label warna hijau.

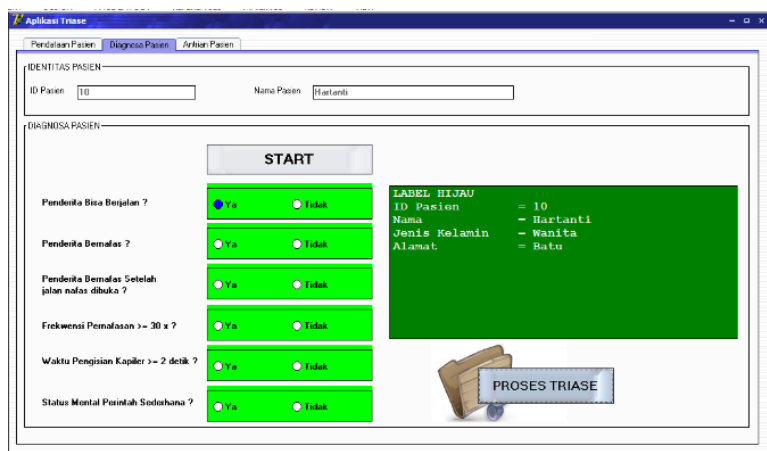

Gambar 9 Hasil triase dengan label hijau

Gambar 10 menunjukkan hasil triase pasien dengan label merah

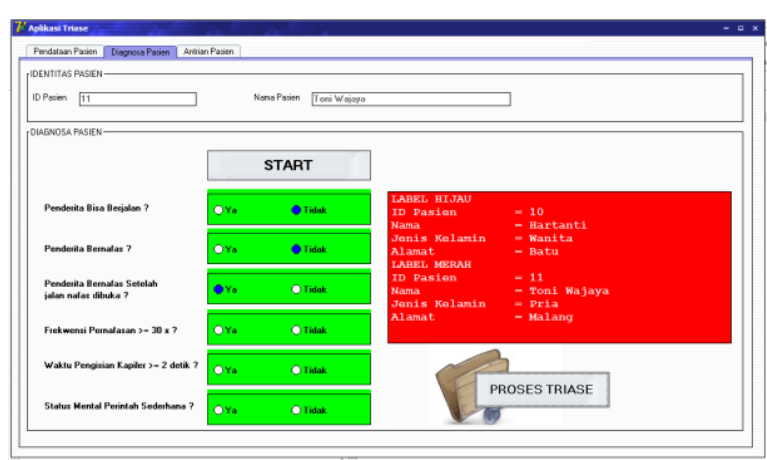

Gambar 10 hasil triase dengan label merah

Gambar 11 menunjukkan hasil triase pasien dengan label kuning

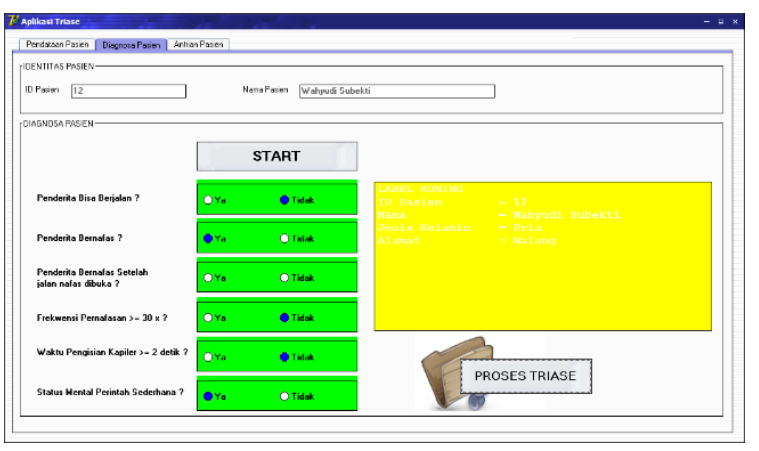

Gambar 11 hasil triase dengan label kuning 
Gambar 12 menunjukkan hasil triase pasien dengan label hitam

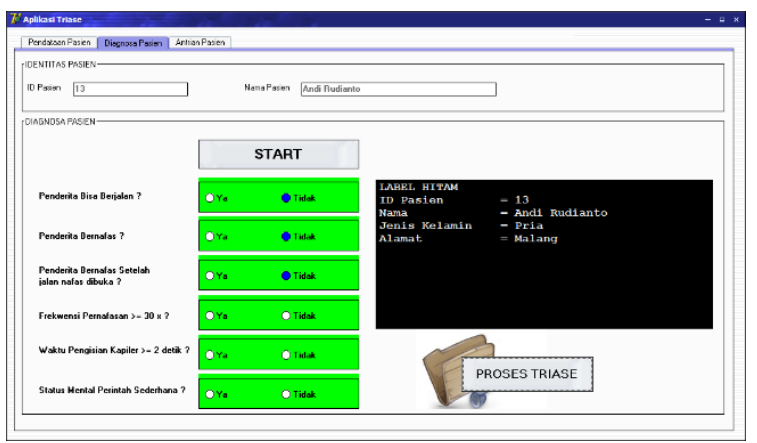

Gambar 12 hasil triase dengan label hitam

Form antrian pasien berisi daftar dari seluruh pasien yang telah didiagnosa. Pada form ini daftar pasien sudah diklasifikasikan berdasarkan label merah, label kuning, label hijau dan label hitam. Form antrian pasien ditunjukkan pada Gambar 13

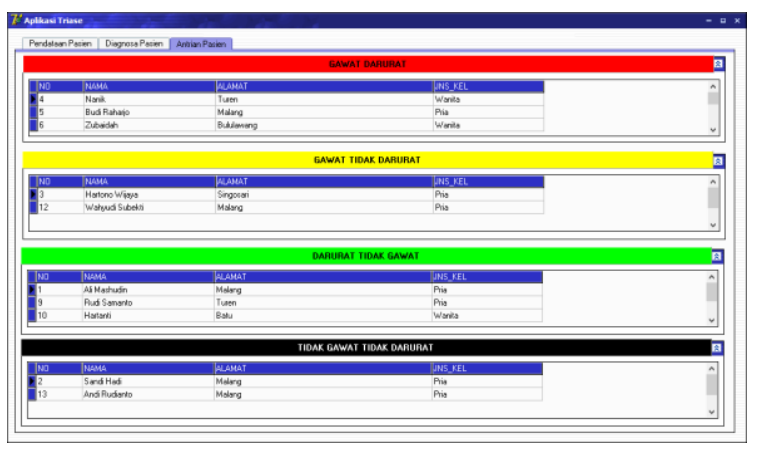

Gambar 13 Form antrian pasien

\subsection{Hasil Pengujian}

Pengujian fungsional dilakukan untuk mengetahui apakah fungsi sudah sesuai dengan kebutuhan atau belum. Pengujian ini juga dilakukan untuk mengatasi error dan menguji validation yang seringkali dilakukan tidak sesuai dengan ketentuan penggunaan aplikasi. Tabel 4 adalah pengujian fungsi menggunakan desktop komputer sebagai bahan uji
Tabel 4 Pengujian Fungsional Program

\begin{tabular}{|l|c|c|}
\hline \multirow{2}{*}{\multicolumn{1}{|c|}{ Fungsional Program }} & \multicolumn{2}{c|}{ HASIL } \\
\cline { 2 - 3 } & Sukses & Gagal \\
\hline Form Utama & $\sqrt{ }$ & \\
\hline Input Biodata Pasien & $\sqrt{ }$ & \\
\hline Delete Biodata Pasien & $\sqrt{ }$ & \\
\hline Ubah Biodata Pasien & $\sqrt{ }$ & \\
\hline Diagnosa label Merah & $\sqrt{ }$ & \\
\hline Diagnosa label Kuning & $\sqrt{ }$ & \\
\hline Diagnosa label Hijau & $\sqrt{ }$ & \\
\hline Diagnosa label Hitam & $\sqrt{ }$ & \\
\hline Form Antrian Pasien & $\sqrt{ }$ & \\
\hline
\end{tabular}

Berdasarkan hasil pengujian fungsional, semua fitur program dapat berjalan.

\section{PENUTUP}

\subsection{Kesimpulan}

1. Aplikasi Triase menggunakan metode START dapat membantu mempermudah dan mempercepat klasifikasi pasien berdasarkan tingkat kegawatan.

2. Berdasarkan hasil pengujian fungsional, $100 \%$ program dapat berfungsi sebagaimana yang diharapkan.

3. Hasil proses klasifikasi kegawatan pasien pada aplikasi Triase menggunakan metode START ini sudah sesuai dengan rule yang telah ditetapkan.

\subsection{Saran}

1. Mengembangkan aplikasi triase dengan menggunakan metode selain START.

2. Mengembangkan aplikasi dalam bentuk mobile.

\section{DAFTAR PUSTAKA}

[1] Hogan, David E. dan Burstein, Jonathan L. 2007. Disaster Medicine Second Edition. Philadelphia : Wolters Kluwer, Lippincott William \& Wilkins.

[2] Talib. 2014. Panduan Lengkap Ms. Access 2013. Jakarta : PT. Elex Media Komputindo.

[3] Kusrini. 2007. Strategi Perancangan dan Pengelolaan Basis Data. Yogyakarta : CV. ANDI OFFSET.

[4] Andoyo, Andreas dan Suyono. 2016. Dasar Pemrograman Delphi. Yogyakarta : CV. ANDI OFFSET.

[5] Sitorus, Lamhot. 2015. Algoritma dan Pemrograman. Yogyakarta : CV. ANDI OFFSET 